\title{
Words, Concepts, and the Middle Way: Language in the Traditions of Madhyamaka Thought
}

\author{
Hans-Rudolf Kantor ${ }^{1,2} \cdot$ Mattia Salvini $^{3}$
}

\section{Introduction}

[...] And what has a nature that goes beyond concepts is not the domain of words; for words, generating concepts, cannot work in respect to what is not the domain of conceptual minds. ${ }^{1}$

Ācārya Prajñākaramati

Buddhist philosophers, everywhere and through the ages, have reflected on the nature and proper role of language. This consistent focus on language stems from a shared tenet: the way we conceptualize and speak of things should not be mistaken for the way things are. According to different Buddhist schools and authors, names and concepts stand in a relationship of varying degrees of indirection and superimposition with their purported referents; the Buddha's own Words must be carefully pondered, by reflecting on their intended distance from the realities and unrealities that they are meant to make manifest.

\footnotetext{
$\overline{1 \text { kalpanāsamatikrāntasvarūpam }}$ ca śabdānām avișayah | vikalpajanmāno hi śabdā vikalpadhiyām avișaye na pravartitum utsahante| Bodhicaryāvatārapañjikā (de La Vallée Poussin 1901-1914, p. 363).

Mattia Salvini

prasajya@gmail.com

Hans-Rudolf Kantor

kantorsan@hotmail.com;

tiantai@cc.hfu.edu.tw

1 Graduate Institute of Asian Humanities, Huafan University, No. 1, Huafan Rd., Shihding Dist., New Taipei City 22301, Taiwan, ROC

2 Present Address: Graduate Institute of Asian Humanities, Huafan University, Taipei, Taiwan

3 Mahidol University, Salaya, Nakhorn Pathom 73170, Thailand
} 
When we turn to the Madhyamaka, the question arises as to whether, in this system, language can at all be referential; compared to other schools, Mādhyamikas consider the limits of linguistic reference to be strikingly circumscribed. Madhyamaka 'answers' to queries about the nature of reality point out, often through examples, that the referential presuppositions of the question are mistaken and will likely affect the way the answer will be understood; thus, the philosophical idiom of the Madhyamaka is varied and very much bound to context. This attitude towards ineffability informs an array of reflections on conceptualization, language and reality, and unique Madhyamaka positions defined by broader Buddhist insights and concerns. This Special Issue focuses on reconstructing a sample of Madhyamaka forays into the effable and the ineffable, by relying on significantly diverse sources, perspectives and methods.

The term Madhyamaka, related to the 'Middle', refers to the philosophical traditions that developed in different areas of Asia from the exegesis of Nāgārjuna's Mūlamadhyamaka-kārikā. Authors who belong to these traditions intend to offer an authentic and plausible interpretation of the Buddha's teachings, and especially the Mahāyāna Sūtras, in the light of Nāgārjuna's philosophical texts-and vice versa. Heirs to their shared sources, Madhyamaka thinkers recurrently focus on similar themes: emptiness, the middle way, the two truths, non-arising, etc., all closely related to the topic of language, its workings, and its proper scope. To unfold the sense of the Buddha's omniscient speech, Mādhyamikas dramatize-in the form of a philosophical debate - the Sütra's suggestion that there is nothing to be known and that the Buddha said nothing at all. In the Mahāyāna Sūtras, language appears as the illusory intersection of a speaker and a listener that never had arisen in the first place, like water in the mirage a thirsty traveler.

Through different idioms and stylistic predilections, the philosophical continuity of Madhyamaka is impressive-especially considering how human thought may resonate rather differently in Sanskrit, Tibetan and Chinese. This Special Issue brings together another array of languages, i.e. different scholarly perspectives from which to observe the role of language in a rich sample of Madhyamaka types. The essays in this volume show how different theoretical predispositions and methods may determine the nature of contemporary reconstructions of Madhyamaka: thus too, this Special Issue sheds light on its main theme-the role of language in the formation of ideas about the 'Middle Way'. An author writing in Chinese may emphasize different aspects of Madhyamaka when compared to a Sanskrit commentator; so too an analytical philosopher's approach may differ from that of someone who prefers continental heuristics, or wide-ranging philological contextualization (not that these three could not be, in principle, the very same person). Different scholarly routes meet here at the crossroads of language, distinguishing each other in marked lines; the contrasts and similarities between ancient exegetes from different parts of Asia offer the backdrop for this encounter. For the ancient and the contemporary interpreters alike, the startling differences derive from the authors' conceptual idiom, rather than solely from divergences in the respective conclusions.

The first essays focus on Indian Madhyamaka and draw from its rich background to reconstruct key features of its tenets. Nāgārjuna's main work, the 
Mūlamadhyamakakārikā, shows familiarity with both Mahāyāna and nonMahāyāna Sūtras (probably in Sanskrit, but with numerous extant Pāli parallels); and with a tradition of Sanskrit Abhidharma that appears to be close to the Sarvāstivāda. Like all philosophers writing in Sanskrit, Nāgārjuna was proficient with non-Buddhist Indian philosophy, grammar, and most likely with a variety of other branches of knowledge.

Nāgārjuna's commentators often help to fill the gaps in our understanding, by offering a plausible context for an otherwise cryptic text. They connect his philosophy to the Buddha's Words (buddhavacana), with a focus on Mahāyāna Sūtras, but including several non-Mahāyāna sources. They often bring the arguments of the root texts to bear upon philosophical discussions that had become of significant interest at their time; such as, to cite an example of a key commentarial concern, the nature and proper means of reliable epistemic validation (pramāna). Nāgārjuna's learned exegetes highlight the implied background of a broader Indic śāstric traditions, offering us glimpses of a lively and highly sophisticated intellectual environment within which their reflections acquire scope and resonance. The commentaries' content and style are likely echoes of monastic debates; they allow us to at least imagine what it would have been to walk through the gates of Nālandā, or at least next to its high walls.

Hideyo Ogawa's article appeals to this Indic background to bring to the fore a recurrent Madhyamaka synonym of 'language': vyavahāra, understood as 'transactional usages', conventional verbal expressions. Ogawa offers an erudite account of the limits of the expressible, emphasizing the tradition of Sanskrit grammar (vyäkarana), the paramount shared heritage of all philosophers writing (or talking) in Sanskrit. Ogawa compares the approach of the influential grammarian/philosopher, Bhartrihari, to that of Candrakīrti; he does so by explicating a crucial passage of the Prasannapadā, wherein a superimposition is intentionally employed to approximate an expression of what is not expressible. Ogawa elegantly demonstrates that different philosophical schools, and different śāstras, share similar concerns and an almost identical conceptual language: to understand Madhyamaka plausibly, one should aim at a broader Indological training. This may require long years of assiduous study, but Ogawa's writing is a convincing argument in favor of taking up the effort.

Similarly, a different area of philology, i.e. the analysis of textual transmission, may offer significant and unexpected keys to better understand the history of Madhyamaka. The transmission of Sanskrit texts, and particularly that of Buddhist Sūtras, is not a stable and predictable process. Variant phrasing may influence the course of philosophical exegesis, opening some doors and closing others. Tom Tillemans discusses one such instance: while the Pāli Samyutta Nikāya depicts the Buddha as saying that he accepts as either existent or non-existent whatever wise people in the world accept to be so, its Sanskrit parallel, quoted by Candrakīrti, drops the qualifier 'wise'. This opens the possibility of reading Candrakīrti as advocating a 'populist' view of conventions and linguistic expressions, wherein a Madhyamaka should just follow what ordinary people customarily accept and say (rather than, as the Pāli passage tells us, what is accepted by the wise). Tillemans considers this to be a natural reading of several passages in Candrakīrti's works, and 
points out a recurrent trend in the Tibetan tradition confirming this 'populist' interpretation. Offering a careful evaluation of this complex exegetical process, and its relationship to the contingencies of textual transmission, Tillemans also notes that new philosophical openings can occur when reading a Tibetan rather than a Sanskrit text. His essay highlights how changes in the wording of a root text may give rise to different understandings of the role of language and conventions as a whole; it does so by discussing the etymology of and sense of key terms (such as samvrti).

Mark Siderits offers a contemporary philosophical solution to what he identifies as an implicit paradox of Madhyamaka: if it is true that 'all conceptualization falsifies', this very statement should be false by its very truth. Siderits reconstructs the sense of the key-term prapañca (which he renders as 'hypostatization'), and discusses the two truths in Abhidharma and Madhyamaka. He then proposes that a radical form of contextual semantics may help understand the paradox and its proper function, solving the problems that may arise from disregarding contexts of utterance. Siderits points out that this would be a cogent move, irrespective of whether Mādhyamikas may have themselves argued anything of the sort. He furthermore demonstrates that this solution allows to read Madhyamaka without discarding classical logic (i.e. without resorting to dialetheia). By casting Madhyamaka in a conceptual idiom that differs from that of the primary source texts, this essay brings to the fore important philosophical themes not explicitly thematized by classical Madhyamaka authors.

The next essay exemplifies a different and possibly complementary approach, in which Indian Madhyamaka thought is primarily reconstructed by reflecting on the specificities of its own idiom. Mattia Salvini focuses on two terms discussed in the previous essays, i.e. 'conventions of the world' (lokasamvrti) and 'elaboration/ prolixity' (prapañca). Starting from considerations about Sanskrit etymology, and offering a survey of different contextual usages, Salvini argues that the two terms are closely related, and that a careful reading of passages where Candrakirti discusses them shows a complex view of layered conventions. This suggests that following 'what is established in the world' (lokaprasiddhi) is a nuanced approach that does not exclude analytical refinement. On the contrary, Candrakīti shows a clear preference for Abhidharmic categories (aggregates, bases, entrances) as valid accounts of conventional truth, discarding the non-Buddhist accounts, based on what he considers to be an imagined 'self', as invalid even conventionally. Salvini discusses the relation between language/conceptualization and conventions in Candrakīrti's thought, arguing that some type of prolixity (prapañca) is useful and instructive in revealing its own conventional nature.

These four initial essays are thematically rather close, occasionally discussing the very same textual passages and offering rather divergent interpretations. These interpretations, in turn, should be considered from two different perspectives - their plausibility as reconstructions of Madhyamaka thought, and their internal philosophical cogency. Our hope is that this variety of opinions-differing even on crucial issues such as whether ultimate truths are, for the Madhyamaka, at all expressible-will offer a glimpse of the complexity of Nāgārjuna's tradition and encourage further reflection. In respect to conventional truths, Madhyamaka authors 
at once emphasize their instructive value and their tendency to falsify, both determined by the relationship between conventional and ultimate truths: the key question is to what extent, and how, conventional expressions may relate to ultimate truths, and whether a refinement of conventions may at all be sensible in a Madhyamaka setting. After reading the four essays, the initial impression may be that the answer could be: yes, no, yes and no, neither yes nor no (not necessarily in this order).

Dan Arnold analyzes the function of language in the Madhyamaka accounts of 'persons' (i.e. the pudgala), putting to philosophical use Tilmann Vetter's suggestion that Nāgārjuna may have been close to the Pudgalavādin: this was a Buddhist non-Mahāyāna school that upheld the existence of an inexpressible 'person', neither identical with nor different from the aggregates. Most Buddhist philosophers, and not only the Pudgalavādin, would agree that the 'person' or 'self' cannot be determined to be either identical or different from the aggregates: Sthiramati, for example, explains that this is the case because a designation (prajñapti) cannot be said to be either identical or different from its own basis (upādāna $){ }^{2}$ and Candrakīrti offers a very similar account in Catuhśsatakațīkā 10.3. ${ }^{3}$ But while it could be argued that Candrakīrti is here offering a rather standard fare (i.e. for most Buddhist philosophers being neither-same-not-different from the aggregates only proves that a person is a convenient conceptual fiction), Arnold reconstructs Candrakīrti's argument as involving mutuality in the relationship between aggregates and self. Not only the self is 'brought into view' (Arnold's rendering of prajñapyate) in reference to the aggregates; the aggregates too are 'brought into view' only in reference to a self/person. Finding support in Candrakīti's treatment of the 'fire and fuel' example, Arnold argues that Nāgārjuna's own treatment of the person/aggregates relation is somewhat closer to the Pudgalavādin. At the very least, it could (should?) be characterized as Pudgalavādin, despite its differences from the historical schools bearing that name. Arnold sets his interpretation within contemporary debates about non-reductionism and the non-eliminable horizon within which any explanation can make any sense in the first place-i.e., persons - through a heuristic excursus into Heidegger's Dasein.

Like Arnold, Jens Schlieter highlights the connection between language and personhood. He relates Nāgārjuna's nominalist stance towards language to the Buddhist denial of a "metaphysical self"- the ontological core corresponding to the concept of "person." Whereas Arnold focuses on arguments and philosophical idioms, Schlieter reconstructs Nāgārjuna's nominalism by considering the social context of personhood. He proposes that Nāgārjuna's analysis of worldly discourse, of the nature of language, and of conceptualization, follows earlier Buddhist nominalist perspectives on the social reality of persons. Schlieter supports this with Pāli and Āgamic sources containing nominalist accounts of both worldly speech and personhood; he then highlights the close relationship between those two accounts, by considering the social context of their production. Buddhists deny that superior moral conduct could either be ascribed to an ethical substance or articulated in a

\footnotetext{
$\overline{2}$ prajñaptisatah svopādānāt tattvānyatvenāvācyatvāt I Pañcaskandhakavibhāṣā (Kramer 2013, p. 4).

3 Suzuki (1994, p. 200).
} 
trans-empirical way; they therefore dismiss the Brahmins' claim to moral superiority and distinction by birth - a claim bent to consolidate a specific social structure. For Schlieter, nominalism is the reductionist approach to the problem of the ontological status and nature of abstract entities, as well as the pertinent analysis of the nature of concepts. That nominalism furthermore occurs in response to a given social order had already been pointed out, for instance, by Edward Conze, with respect to Western nominalism and its criticism of feudal society.

Buddhist nominalism takes the Brahminic notion of the self to be a social construct, yet it does not rule out using the name 'self'. It furthermore encourages the user to disentangle words and objects, and to disidentify from both, in order to achieve a salutary state of detachment. Thus, Nāgārjuna's understanding of $s \bar{u} n y a t \bar{a}$ - crucial to his analysis of conventional speech and entailing the heuristics of the two truths-developed from earlier Buddhist nominalism; this, in turn, as Schlieter argues, originated from the observation of social phenomena and their nature.

Ye Shaoyong presents a novel exegesis of Nāgārjuna, focusing on a selected portion of his works and striving to find the fundamental keys to make sense of Nāgārjuna's philosophical project. He distances himself from the Madhyamaka commentarial tradition (and from several other scholars), arguing that it had superimposed a heuristic framework alien to Nāgārjuna's own concerns; according to Ye Shaoyong, Nāgārjuna was an 'epistemological nihilist' who offered no concession to conventional truth beyond recognizing its didactic value, while the later tradition sought a harmony and balance between the two truths that is not faithful to Nāgārjuna's more drastic intent. In other words, there is no ontological relationship between the two truths, nor is it true that the two are mutually supportive in any way; this is argued for by interpreting Nāgārjuna's refutation according to a 'confinement principle', which entails that every concept can be shown to be non-referential on the basis of the logical tension between its static and dynamic aspects. Ye Shaoyong acknowledges that this reading may be found to contradict parts of Nāgārjuna's work that he has not explicitly discussed in his paper, and leaves readers with a cliffhanger: future publications will tackle this difficulty, expanding on his new conceptual commentary to the philosophy of the Middle Way. His ambitious intellectual project is presented as the most coherent and rational way of reading Nāgārjuna, and we may expect that this article shall be just the beginning of a continued and consistent effort to demonstrate this claim.

Jan Westerhoff offers a clear and accessible reconstruction of Nāgārjuna's theory of language, centering on two relatively less studied works, the Vigrahavyāvartan̄ and the Vaidalyaprakarana. The first work is the longest available example of Nāgārjuna's commentarial prose, and starts with an analysis of the nature and capacities of words by describing their arising in terms of traditional Sanskrit phonetics. Westerhoff highlights the relationship between Nāgārjuna's own theory and his rebuttal of an opponent upholding a theory of realistic semantics (possibly close to the Nyāya system). Westerhoff then takes up some passages wherein Nāgārjuna articulates a view of language specifically connected to Buddhist positions, such as momentariness and mereology. In the Vaidyalyaprakarana Nāgārjuna criticizes the possibility that the different parts of a syllogism could exist 
simultaneously, due to their being expressed in diachronic succession. The argument explicitly endorses (and perhaps necessitates) the doctrine of momentariness, and Westerhoff brings out some further implications while interpreting it in the light of that principle. Furthermore, the latter parts of Westerhoff's essay demonstrate how Buddhist mereological assumptions bear on Madhyamaka accounts of language.

Lai Yan Fong discusses the relationship between Madhyamaka and classical Indian logic from a different perspective, and using different sources, i.e. a key treatise of Bhāviveka preserved only in Chinese translation. Nāgārjuna's criticism of Nyāya categories, and his ultimate refutation of pramāna, did not prevent later Madhyamaka authors to assimilate some features of Dignāga's new epistemic framework within their own exegesis of the Mūlamadhyamakakārikā. The trend, in fact, begins with Bhāviveka; and Lai Yan Fong's presentation highlights very well that his understanding of the workings of pramanna is closely linked to a specific view about the way in which words relate to their referents. This article demonstrates that Bhāviveka, while employing key categories from Dignāga such as the sāmānya and the basic elements in the statement of a reasoning, recontextualizes them to avoid the ontological commitments that Dignāga understood as a necessary implication of his pramāna terminology. By a careful reconstruction of Bhāviveka's solution to a problem in 'inference for others' (parārthānumāna), Lai Yan Fong introduces us to a crucial moment in the history of Buddhist philosophy, when a Madhyamaka author showed that Dignāga's system of pramāna could be integrated within the philosophical exegesis of Nāgārjuna without compromising, and rather enhancing, the Madhyamaka presentation of emptiness. This started a long and very rich tradition of both emulation and disagreement, in India and elsewhere, which highlights the close connection between the chosen language of philosophical debate and the necessary ontological commitments that allow that language to function.

A Sinic mirror of this debate is to be found in Lin Chen-kuo's essay, which presents another discussion about the proper role of syllogistic statements, and thus pramāna, in the understanding and expression of emptiness-in this case, the emptiness of motion. Not unlike certain debates within the Indic and Tibetan exegetical traditions of Madhyamaka, the primary point of dispute is here whether and how the formal requirements of hetu-vidy $\bar{a}$ should be employed in presenting a Madhyamaka refutation. By way of contrast with the previous paper, readers will recognize that, despite certain thematic continuities, Zhencheng's employment of syllogistic formats has a different flavor and responds to concerns that are not identical; remarkably, this is a Ming dinasty response to a much earlier interpretation of Nāgārjuna-an interpretation that had remained almost undisputed through centuries of Chinese Buddhism. This paper offers a precious glimpse of a rather less known East Asian debate on pramāṇa and their role in Madhyamaka, adding perspective to the recurrent question of the role of syllogistic forms in verbal and conceptual elaborations on emptiness.

Brook Ziporyn offers a broader introduction to the world of Chinese Madhyamaka. His exegetical essay includes a partial translation of a treatise by Kumārajīva's influential disciple, Seng Zhao-the first indigenous Chinese 
Madhyamaka master. Seng Zhao deals with prajñā as a form of wisdom to be distinguished from ordinary knowledge; the latter affirms or identifies a fact as a determinate state of affairs. According to Ziporyn, Seng Zhao elaborations on prajñ $\bar{a}$ anticipate more explicit and evident later discussions in the Tiantai-school, accounting for a characteristic development in Chinese Madhyamaka. Ziporyn's expression 'ontological ambiguity' adumbrates that characteristic and comes close to Kantor's 'ontological indeterminacy.' The article deals with the Chinese Buddhist elaborations on the function of language: to adequately signify 'ontological ambiguity.' This implies a paradox of indeterminacy qua/yet determinacy. According to Ziporyn, Seng Zhao, as well as the later Tiantai masters, argue against a determinate mode of facts-against a state of being independent from intentionality and from any other being; a state in which the causal relation of what determines and what is determined excludes otherness, its own contradiction. The determinate mode of facts excluding otherness, which for Ziporyn is linked to the Sanskrit term svabhāva, correlates with a dualistic sense of truth, the disjunctive relation of either/or, called 'bivalent truth.' Seng Zhao's treatment of prajñ $\bar{a}$ without knowledge, deeply rooted in the Madhyamaka sense of śūnyatā and pratītyasamutpāda, dismisses all the exclusions of bivalent truth. The referent of wisdomultimate truth realized in its emptiness of svabhāva, must remain indeterminate. Paradoxically, if the indeterminacy of prajñ $\bar{a}$ and of ultimate truth excludes its own contradiction, it contradicts itself. In other words, indeterminacy excluding determinacy again is nothing but determinacy. Therefore, Seng Zhao's elaboration on prajñ $\bar{a}$ and ultimate truth develops a notion of emptiness wherein 'nothing' is the opposite of the 'exclusion of everything'—namely 'no one thing in particular,' i.e., anything, which, according to Ziporyn, is the 'Chinese nothing' closely related to Daoist nothingness. Whereas the 'Indian nothing' is just the denial of any thing, the 'Chinese nothing' is an affirmation of 'anything' that in fact neither affirms any thing, nor truly denies anything; it advances indeterminacy at the linguistic level, developing a paradoxical form of language wherein the katophatic and apophatic modes coincide. This is the sense in which 'ontological ambiguity' refers to the topic of language.

In the concluding essay, Hans-Rudolf Kantor reflects on the ambiguous role of language, described by Chinese Madhyamaka authors as simultaneously deceptive and instructive about its own deceptiveness. In the course of an extended discussion, Kantor shows how Madhyamaka paradoxes point to beneficial performative contradictions, which are nevertheless resolved in the very recognition of their pragmatic necessity. Distancing himself from a dialetheic reading of Madhyamaka, or from the recurrent idea that, for Madhyamaka, there is no ultimate truth, Kantor emphasizes that the two truths stand in a mutual relation wherein, for Chinese exegetes, the proper meaning of emptiness can be disclosed through a familiarized awareness of their dynamic function. His essay returns to a theme discussed in the initial sections of this Special Issue, showing how Chinese Madhyamaka authors draw from a pool of Indic and Sinic traditions to articulate feasible ways of 'expressing the inexpressible'. As we may expect, the answer here too lays in discarding a rigidly dualistic perception of 'conceivable' and 'inconceivable', 
'expressible' and 'inexpressible', etc., to then elicit an awareness of mutuality qua non-duality.

The Special Issue thus comes to an end suggesting the image of a wholesome hermeneutic circle, wherein starting from Indian Madhyamaka and its background will help in understanding Chinese Madhyamaka and its treatment of similar themes, and vice versa; and wherein different scholarly approaches are mutually enriching and beneficial. We hope that this multifaceted engagement with Madhyamaka may offer a philosophically instructive reading experience about the functions and limits of words.

Acknowledgements This Special Issue is the outcome of the conference "Language in the Traditions of Madhyamaka Thought," organized by Huafan University in Taipei (June 27-29, 2014). We thank both Huafan University and the Ministry of Science and Technology (MOST) of Taiwan for their financial support; and we are grateful to all the participants. We were able to finalize the publication thanks to the kind support of the Buddhist Studies Research Cluster of the Faculty of Social Sciences and Humanities, Mahidol University, that organized a series of lectures and readings on Madhyamaka and Buddhist Philosophy in Sanskrit and Chinese, in July 2019.

\section{References}

de La Vallée Poussin, L. (1901-1914). Bodhicaryāvatārapañjikā: Prajñākaramati’s Commentary on the Bodhicaryāvatāra of Çāntideva, Edited with Indices (Vols. 983, 1031, 1090, 1126, 1139, 1305 and 1399 of Bibliotheca Indica). Calcutta: Baptist Mission Press.

Kramer, J. (2013). Sthiramati’s Pañcaskandhakavibhāṣā. Part I (Critical ed.). Beijing-Vienna: China Tibetology Publishing House/Austrian Academy of Sciences Press.

Suzuki, K. (1994). Sanskrit Fragments and Tibetan Translation of Candrakīrti's Bodhisattvayogācāracatuhśatakațikā. Tokyo: The Sankibo Press.

Publisher's Note Springer Nature remains neutral with regard to jurisdictional claims in published maps and institutional affiliations. 